\title{
ENVIRONMENTAL RISK ASSESSMENT FOR NEODRYINUS TYPHLOCYBAE, BIOLOGICAL CONTROL AGENT AGAINST METCALFA PRUINOSA, FOR AUSTRIA
}

\author{
GUDRUN STRAUSS \\ Austrian Agency for Health and Food Safety, Institute for Sustainable Plant Production, Spargelfeldstraße 191, A-1220 Wien, Austria \\ Corresponding author: gudrun.strauss@ages.at
}

\begin{abstract}
The potential environmental risks of Neodryinus typhlocybae, a parasitic wasp from North America, were evaluated with regard to its safe use as an exotic biocontrol agent for the planthopper Metcalfa pruinosa in Austria. Following an earlier host range study of N. typhlocybae conducted in the laboratory, the present study assessed the potential for establishment and spread as well as negative indirect effects on non-target organisms. The potential release sites in Austria were analysed for matching of the climatic requirements for establishment of N. typhlocybae. The two proposed release locations, Vienna and Graz, have a predominantly similar climate to the parasitoid's region of origin, though the comparably cooler mean summer temperatures might result in a low emergence rate of the partial second generation. The natural spread potential of $N$. typhlocybae was reviewed and is considered to be sufficiently good for released individuals to reach nearby sites infested with M. pruinosa. However, a perceptible spreading of $N$. typhlocybae females only occurs a few years after release and seems to be strongly dependent on the host density. Gelis areator, a hyperparasitoid of N. typhlocybae known to occur in Austria, might have negative effects on the population of the beneficial organism. Advantages and disadvantages of chemical and biological control methods against M. pruinosa were evaluated. It is concluded that N. typhlocybae is very well suited as a biological control agent for M. pruinosa in Austria, as no adverse effects on non-target species are expected but its release offers advantages with regard to sustainable and environmentally friendly pest management.
\end{abstract}

Keywords: classical biological control, environmental impact, harmful effects, Metcalfa pruinosa, Neodryinus typhlocybae, parasitoid

\section{Introduction}

Since the North American planthopper Metcalfa pruinosa (Say 1830) (Hemiptera: Flatidae) was first reported from northern Italy in 1979, it has spread into new areas of the Mediterranean and is now widely distributed in several European countries (Nicoli 1997; Strauss 2009). This polyphagous planthopper species has become a serious pest in agriculture and public green space by forming dense populations which subsequently cause severe damage in orchards, vineyards, ornamentals and urban areas (Zangheri and Donadini 1980; Girolami and Camporese 1994). Large infestations of M. pruinosa may weaken the host plants by excessive phloem sucking and honeydew production which supports the growth of sooty moulds on affected plants, resulting in reduced fruit quality and leaf photosynthesis but also in quality damage in ornamentals.

Native natural enemies in the Mediterranean region have not effectively controlled $M$. pruinosa so far (Greatti et al. 1994). The import and release of an exotic natural enemy from the area of origin of M. pruinosa was considered a promising control strategy. The parasitic wasp Neodryinus typhlocybae (Ashmead 1893) (Hymenoptera: Dryinidae) has therefore been released in some European countries for the control of mass occurrences of $M$. pruinosa (Girolami and Camporese 1994; Ciglar et al. 1998; Tommasini et al. 1998; Malausa 2000; Žežlina et al. 2001; Anagnou-Veroniki et al. 2008; DAISIE 2008).
In Austria, the distribution and phenology of $M$. pruinosa in Vienna has been monitored since 2003, as populations of $M$. pruinos a have also established in urban areas, private gardens and public green spaces in Vienna and Graz. Based on this monitoring, it is assumed that this planthopper is likely to spread locally in the short term and occupy a great part of the area suitable for establishment if no plant protection measures are taken (Kahrer et al. 2009; Strauss 2010). Release of N. typhlocybae is therefore also being considered in Austria to prevent further spread and economic impact of the pest.

The authorization as a plant protection product (PPP) for the import and release of a biological control agent (BCA) is a compulsory requirement in Austria, in a similar way to conventional plant protection products (Pflanzenschutzmittelgesetz 2011). For the authorization of biological control agents as PPP, comprehensive information on the environmental effects of the specific organism is necessary.

Consequently, with regard to the safe use of $N$. typhlocybae as a biocontrol agent in Austria an environmental risk assessment (ERA) was performed based on international standards (EPPO 2000; OECD 2004; FAO 2005). In a first step, the host specificity of $N$. typhlocybae was investigated in laboratory host range tests with respect to non-target plant- and leafhopper species in Austria (Strauss 2009). The results of these tests support the assumption that $N$. typhlocybae is host specific to species of the family Flatidae, of which only the introduced pest 
species occurs in Austria. N. typhlocybae was also used as a model organism to check if the existing international regulatory standards for the import and release of BCAs are useful for assessing the environmental risks of parasitoids.

The objectives of the present study were to assess (1) the potential for the establishment and (2) spread of N. typhlocybae in two locations in Austria with M. pruinosa infestation, as well as (3) its potential negative indirect impacts on native predators, (4) the negative effect of naturally occurring hyperparasitoids on N. typhlocybae, and finally (5) to provide the competent national authority with an overall recommendation as to whether the release of $N$. typhlocybae would pose an unacceptable risk to the environment.

\section{Material and Methods}

This environmental risk assessment was compiled on the basis of regulatory documents produced by international organizations on the import and release of candidate invertebrate biological control agents (IBCAs) (EPPO 2000; OECD 2004; FAO 2005). Data from scientific literature, meeting reports, records from insect collections, personal information from insect taxonomists and various internet databases on biogeography for the relevant species (Nearctica 1998; Fauna Europaea 2004; DAISIE 2008) and climate (World Climate 1996; Zentralanstalt für Meteorologie und Geodynamik 2002) were used to determine the following risk factors for $N$. typhlocybae in Austria, as proposed by van Lenteren et al. (2006): the potential of establishment and spread, the host range and direct and indirect effects on non-target organisms.
The objective of introducing $N$. typhlocybae into Austria is to establish self-sustaining and multiplying populations on $M$. pruinosa infestation sites in Vienna $\left(48^{\circ} 14^{\prime} \mathrm{N} 16^{\circ} 21^{\prime} \mathrm{E}\right)$ and $\mathrm{Graz}\left(47^{\circ} 5^{\prime} \mathrm{N} 15^{\circ} 27^{\prime} \mathrm{E}\right)$. The release of N. typhlocybae in Austria would represent the northernmost release in the field in Europe. Therefore, the climate of the proposed release sites, Vienna and Graz, was compared to that of the original area of $N$. $t y$ phlocybae in North America. In Austria, the N. typhlocybae strain originally deriving from Connecticut, USA would be released. For this purpose, the progression of the mean daily temperature in the reference locations New Haven (Connecticut, USA) and Toronto (Ontario, Canada) was compared with that in Vienna and Graz to see if deviations exist between the locations. Toronto was chosen because it is one of the northernmost locations in North America where N. typhlocybae occurs. Distribution data for N. typhlocybae in North America and Europe were used to create distribution maps using ArcMAP (ESRI ${ }^{\circledR} \operatorname{ArcMAP}^{\mathrm{TM}}$ Version 10.0).

\section{Results}

\section{Probability of establishment}

The purpose of this section is to analyse climatic similarities or differences between the native area and the area of intended release of $N$. typhlocybae that could affect its establishment. In North America, the geographical distribution of $N$. typhlocybae occurs across a broad climatic area, from southern Ontario, Canada, to almost all eastern states of the USA. The parasitoid has a local occurrence in Arizona (Cochise County only) and Mexico (Baja California Sur) (Fig. 1).

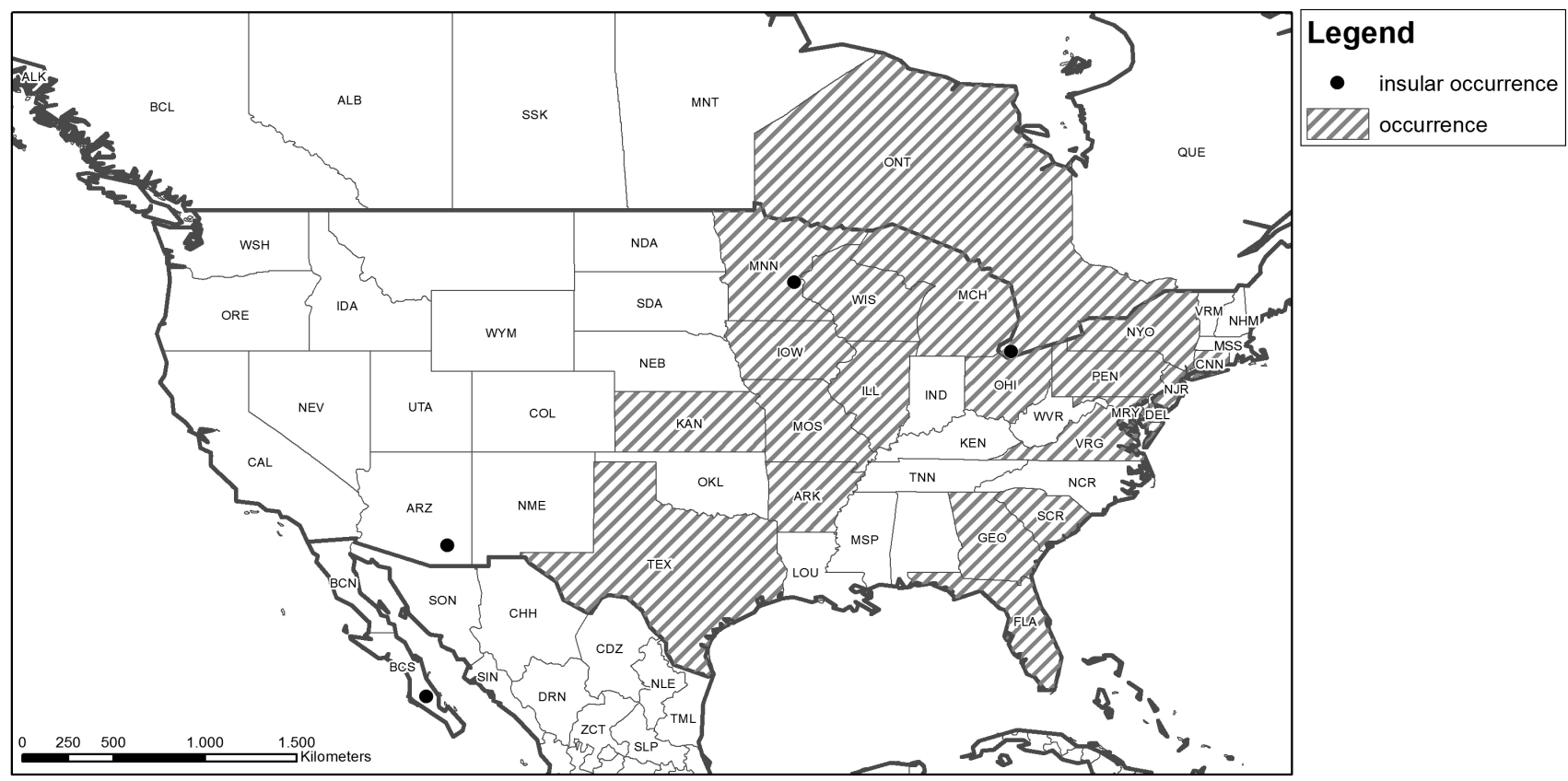

Fig. 1 Natural distribution of Neodryinus typhlocybae in North America. Shaded areas indicate occurrence on a state level and not actual territory occupied by this species. 


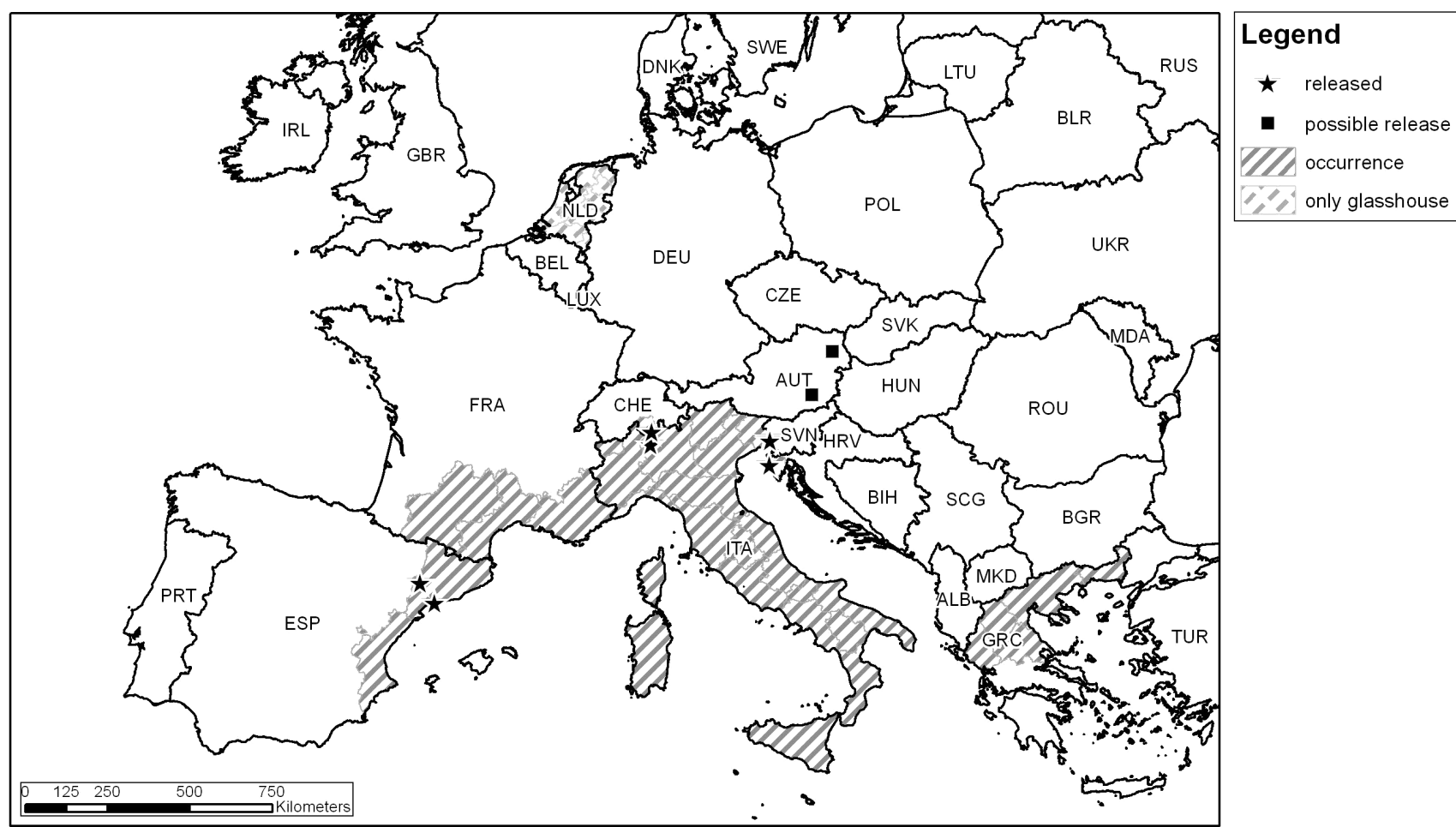

Fig. 2 European countries where Neodryinus typhlocybae has been released as a biocontrol agent for the introduced planthopper Metcalfa pruinosa. Shaded areas indicate occurrence on a national or regional level and not actual territory occupied by this species.

Since 1987, N. typhlocybae cocoons have repeatedly been collected in several states in the USA and introduced into Italy. Neodryinus typhlocybae populations released in Europe originate from Connecticut (Girolami and Mazzon 1999). Further releases have been undertaken in the canton of Ticino (Coldrerio and Carasso) in Switzerland (Jermini et al. 2000), in western Slovenia close to the Italian border (Nova Gorica and Volčja Draga) (Žežlina et al. 2001), in Istria in Croatia (Poreč) (Ciglar et al. 1998; B. Barić, pers. comm.), and in southern France (Malausa et al. 2003), as well as in Catalonia and Valencia in Spain (A. Soto Sanchez, pers. comm.) (Fig. 2).

In the classical biological control strategy, permanent establishment of the non-native organism in the new environment is an essential pre-requisite for a successful pest management (Bale 2011). In Austria, it is desired that a stable population of $N$. typhlocybae be established in the areas infested by $M$. pruinos $a$ and reduce the latter's density. Information on the natural range of distribution of N. typhlocybae in North America and in the release areas in Europe was summarised to determine its climatic tolerance (Fig. 3).

The two Austrian release sites for N. typhlocybae are not only located further north than the previous release areas in Europe, they are even further north than the northernmost occurrence of $N$. typhlocybae in North America. In moderate climatic zones, N. typhlocybae adults emerge from the middle of June, parasitise M. pruinosa larvae and build cocoons by the end of June.
The partial second generation emerges from these cocoons in July and August (Lucchi and Wilson 2003; Alma et al. 2005). Thus, the climate from June to August of these two novel sites was assessed to see whether it matches the climatic requirements of the exotic parasitoid for establishment, as it is known that temperature is an important factor influencing the efficacy of wasps as biological control agents (Wajnberg et al. 2007). The mean daily temperatures of Vienna, Graz, New Haven and Toronto were compared in order to analyse the climatic deviation with respect to the developmental season of N. typhlocybae. As far as is known from the literature, N. typhlocybae has its northernmost occurrence near Toronto $\left(43^{\circ} 70^{\prime} \mathrm{N}\right.$, $79^{\circ} 40^{\prime} \mathrm{W}$ ), Canada (Steve Paiero, pers. comm.).

Graz has the lowest mean daily temperature from the middle of June until the middle of October (Fig. 3), with $1.3^{\circ} \mathrm{C}$ and $2.6^{\circ} \mathrm{C}$ lower in July than Toronto and New Haven, respectively. This might have negative implications for the emergence rate of the second incomplete generation of N. typhlocybae. Because of the cooler summer temperatures, a greater proportion of the second generation could go into diapause and emerge only in the following year. The second generation, however, has an important role in the spreading of the beneficial insect (see probability of spread). In Vienna, the average daily temperature during the developmental period of the wasp is one to two degrees Celsius below the temperature of New Haven, but similar to the temperature of Toronto, where N. typhlocybae is established. 


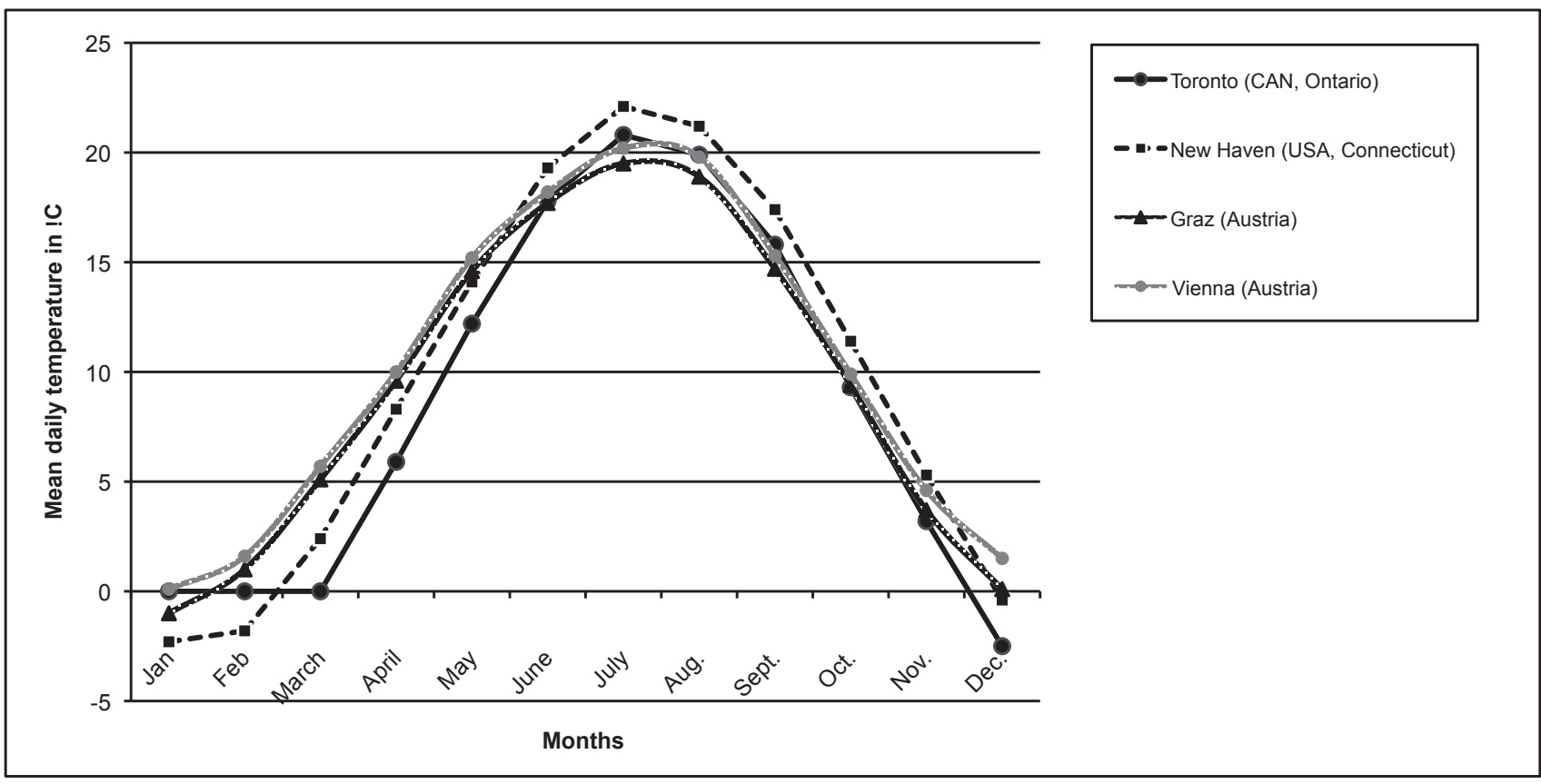

Fig. 3 Comparison of the mean daily temperature in Vienna and Graz, two prospective release sites in Austria, with locations in North America where Neodryinus typhlocybae is established. Vienna (latitude: $48^{\circ} 14^{\prime} \mathrm{N}$, longitude: $16^{\circ} 21^{\prime} \mathrm{E}$ ), Graz (latitude: $47^{\circ} 5^{\prime} \mathrm{N}$, longitude: $15^{\circ} 27^{\prime} \mathrm{E}$ ) (Source: ZAMG (2007), period 1971-2000), New Haven (latitude: $41^{\circ} 30^{\prime} \mathrm{N}$, longitude: $72^{\circ} 90^{\prime} \mathrm{W}$ ) (Source: www.worldclimate.com, period: 1781-1970) and Toronto (latitude: $43^{\circ} 70^{\prime} \mathrm{N}$, longitude: $79^{\circ} 40^{\prime} \mathrm{W}$ ) (Source: www.worldclimate.com, period: 1840-1990).

\section{Probability of spread}

For classical control agents high dispersal ability is important to ensure that the beneficial organism becomes well distributed within the release area, and to reduce the number of release points per area and hence costs (McDougall and Mills 1997; Wright et al. 2001). The scientific literature on the spread potential of N. typhlocybae in Italy, France and Slovenia was reviewed with regard to the dispersal rate per year and important influencing factors such as habitat structure and anthropogenic influence to make predictions for the dispersal of N. typhlocybae in the target regions in Austria. It is important to determine the potential for dispersal of the parasitoid in order to evaluate the probability of temporal and spatial encounter between the biocontrol agent and the pest species.

Generally, spread of N. typhlocybae occurs by flying and is facilitated by host population size, the occurrence of the two generations per year, contiguous vegetation and the longevity of females of ten days (Girolami and Mazzon 1999). Furthermore, N. typhlocybae could also be spread indirectly via parasitised larvae of $M$. pruinosa, by the transport of plants with cocoons by humans and via wind transport of leaves with cocoons.

The results on the dispersal potential of $N$. typhlocybae in the literature differ and range from $30 \mathrm{~m}$ to $20 \mathrm{~km}$ per year (Girolami et al. 1996; Girolami and Mazzon 1999). In northern Italy, N. typhlocybae spread $750-2500 \mathrm{~m}$ in 6-18 months after release (Cenderello 2006). In general, the spread potential of $N$. typhlocybae is sufficiently good to reach and colonize other locations with M. pruinosa, but host density apparently influences the movement of N. typhlocybae. In Italy, Girolami and Mazzon (1999) reported a sudden and rapid increase of $N$. typhlocybae in the area of Padova-Legnaro (Veneto region, Northern Italy), which spread up to $10 \mathrm{~km}$ in one year. In the years before, the rate of spread was very low, reaching just a few hundred meters in 3-4 years. These authors and also Malausa et al. (2003) concluded that $N$. typhlocybae females stayed at the release sites as long as the host density was sufficiently high, but spread actively when host density was declining and were then found several hundred meters away from the release points.

Neodryinus typhlocybae has a partial second generation, from adults emerging in July/August and parasitizing the remaining $M$. pruinosa larvae. Wasp larvae of this generation overwinter in the cocoon (Girolami et al. 1996). By the beginning of August, however, hardly any larvae of M. pruinosa remain, but mainly the adults are present. In the USA, N. typhlocybae reproduces on three flatid species that have somewhat different development times and phenologies (Wilson and McPherson 1981). Thus, the appropriate host stages for oviposition are present for female wasps of the second generation and the life cycle is not interrupted. It is assumed that the adults of the second generation of $N$. typhlocybae spread over greater distances because females need to search for new host patches with the appropriate larval stages for reproduction, the host larvae numbers already having decreased by then. In North America, the percentage of the emerging second generation varies from $20-80 \%$, depending on the climatic region. Parasitoid populations originating from Texas have a higher percentage of bivoltism than populations descending from Connecticut (Tommasini et al. 1998). The average percentage of bivoltism of N. typhlocybae in Italy and France, which have a warmer climate 
than Austria, is about 30-40\% (Malausa 2000; Girolami and Mazzon 2001). For example, the mean daily temperature in Udine/Campoformido (latitude: $46^{\circ} \mathrm{N}$, longitude: $13^{\circ} 10^{\prime} \mathrm{E}$, source: World Climate, period: 1803-1991) in June and July is $2.8^{\circ} \mathrm{C}$ and $3.1^{\circ} \mathrm{C}$ higher than in Graz. For Austria, it is expected that a smaller portion of the second generation of $N$. typhlocybae will emerge due to the cooler climate, and that spread will be slower.

For the successful spread of $N$. typhlocybae the habitat structure plays an important role. The widespread presence of green areas, gardens and hedges aids the expansion of population of N. typhlocybae (Girolami and Mazzon 1999). Spread of N. typhlocybae to host-free places has no relevance, since establishment would be impossible as no other host species occur in Austria (Strauss 2009).

\section{Negative indirect effects on the native fauna}

Introduced exotic natural enemies may negatively affect the abundance of native predators or parasitoids that use the same prey or host (Messing et al. 2006).

Various naturally occurring generalist predators have been observed to prey upon $M$. pruinosa, particularly Coccinellidae (Coleoptera) e.g. Coccinella septempunctata (L., 1758), Miridae (Hemiptera) and Chrysopidae (Neuroptera), as well as various bird species (Barbattini et al. 1991; Greatti et al. 1994). As these native predators consume small numbers of $M$. pruinosa individuals and do not depend on them as their only source of prey, competition with or displacement of these species through the introduction of $N$. typhlocybae is very unlikely (Zandigiacomo and Villani 2003).

\section{Risk/benefit analysis of the use of N. typhlocybae}

The last step of a comprehensive environmental risk assessment is the comparison of the risk/benefit of the biocontrol method with other pest management methods (van Lenteren et al. 2008). Small populations of young instars of $M$. pruinosa can be controlled with pesticides in production sites as well as in public and private green spaces, but several pesticide treatments per season are required because of the prolonged hatching period (Malumphy et al. 1994). For the control of sucking insects and leafhoppers in viticulture and orchards in Austria in 2011, Imidacloprid (Confidor 70 WG, Reg. No. 2602), Fenpyroximat (Samba K, Reg. No. 2762), Chlorpyrifos-methyl (Reldan 2E, Reg. No. 2225) and Indoxacarb (Steward, Reg. No. 2737) are approved. In Vienna, two bigger infestation sites $\left(51,000 \mathrm{~m}^{2}\right.$ and $\left.3500 \mathrm{~m}^{2}\right)$ and three smaller sites $\left(\sim 200-500 \mathrm{~m}^{2}\right)$ have been detected since 2003 (Kahrer et al. 2009). Costs of insecticide treatment were considered low and amounted to a maximum of 70 Euro/ha for one application. In the long term, however, more working hours would be needed for chemical control than for biological control due to the necessity of repeated applications, and the costs of equipment and amortisation also have to be considered. Furthermore, no pesticide application is permitted for containment in other sites of potential occurrence of $M$. pruinosa, such as natural areas, which may serve as over-wintering sites from which it may infest nearby cultivated land. Thus, a major disadvantage of insecticide treatment is that pesticide treatment would not control the pest completely in all infestation areas and no long-term control would be achieved.

Additionally, insecticides could negatively affect non-target arthropods such as honeybees which collect honeydew excretions of $M$. pruinosa (Greatti and Barbattini 2003). Imidacloprid and Chlorpyrifos-methyl are toxic to honeybees and their application is not allowed if honeybees are present; Fenpyroximat and Indoxacarb are toxic to beneficials, e.g. Ichneumonidae (Suchail et al 2000; Bundesamt für Ernährungssicherheit 2012).

Releases of N. typhlocybae in Vienna could be considered for three of the five infested sites, because the other two sites are close enough (up to $3 \mathrm{~km}$ away) for the biocontrol agent to colonize them by natural spread. A relatively small population of about $200 \mathrm{~N}$. typhlocybae cocoons per site is assumed to be sufficient for the release and control of $M$. pruinosa, based on the experience in Slovenia where N. typhlocybae established successfully (Žežlina et al. 2001).

Classical biological control of $M$. pruinosa with $N$. typhlocybae is considered to be economically feasible in terms of material costs, application and working hours in the long term. Additionally an evaluation of effectiveness for chemical and biological control would be needed. Alma et al. (2005) developed a sampling plan to estimate N. typhlocybae cocoon density and the impact on M. pruinosa, which can be applied easily in the field. The cost for a post-release evaluation of $N$. typhlocybae's parasitisation rate and of assessing efficacy of the insecticide treatment is considered to be comparable, therefore. In Italy, France and Slovenia, the release of N. typhlocybae led to a high parasitisation rate (from below $50 \%$ to up to $80 \%$ ) and thus to a considerable reduction of the pest and damage (Visentini 1998; Girolami and Mazzon 1999). Different authors frequently report that crop damage has declined to below the economic damage threshold after release of the beneficial insect (Malausa 2000; Žežlina et al. 2001; Chapelle et al. 2002; A. Soto Sánchez pers. comm.), albeit without stating exact figures about the size of the reduction.

\section{Negative effects on N. typhlocybae}

The main interaction factors resulting in negative effects in biological control programmes are hyperparasitism, predation of cocoons and cultivation practices. High levels of hyperparasitism can lead to a strong decrease in the population of the primary parasitoid and thus to a reduced level of pest control (Höller et al. 1993). In Europe, N. typhlocybae is known to be parasitised by 
the following four parasitic wasp species: Cheiloneurus boldyrevi (Trjapitzin and Agekyan 1978) (Hymenoptera: Encyrtidae), Gelis areator (Panzer 1804) (Hymenoptera: Ichneumonidae), Callitula bicolor (Spinola 1811) and Pachyneuron muscarum (L., 1758) (Hymenoptera: Pteromalidae) (Girolami et al. 1996; Villani and Zandigiacomo 1999; Olmi 2000; Viggiani et al. 2004). Of these, only G. areator occurs in Austria (Fauna Europaea 2004). As $G$. areator also parasitises the key grapevine pest Lobesia botrana (Denis and Schiffermüller 1776) (Lepidoptera: Tortricidae), biological control of $M$. pruinosa with $N$. typhlocybae in vineyards could be negatively influenced through the hyperparasitisation of N. typhlocybae by G. areator. Furthermore, the cocoons of N. typhlocybae on autumn foliage on the ground are particularly at risk of being eaten by insectivorous birds, rodents and entomophagous insects. Tommasini et al. (1998) reported that $48-60 \%$ of the cocoons on the ground were eaten. Also human interaction such as chemical weed control or removal of autumn leaves with the overwintering cocoons of $N$. typhlocybae on them could negatively affect the population of N. typhlocybae and reduce the biocontrol effect on $M$. pruinosa.

\section{Discussion}

In the course of the literature study for the environmental risk assessment for $N$. typhlocybae it was noticed that, with just a few exceptions, potential risks of the release of exotic invertebrates for the control of pests have not been routinely assessed in pre-release evaluations, and that screening information on the impact on non-target organisms is required in only a few countries (van Lenteren et al. 2006; Stewart et al. 2007; Bale 2011). To mitigate the risk associated with the introduction of exotic natural enemies of plant pests in a new geographic region, the threat to the native fauna, in particular, needs to be assessed before a new species is released (Hoddle 2004; Bélanger and Lucas 2011; Maisonhaute and Lucas 2011).

In Europe, the regulation of import and release of invertebrate biological control agents (IBCA) has not yet been harmonised (Bigler et al. 2005; Bale 2011). Indeed, although environmental risk assessment is an emerging issue for both pest and biological control organisms, the new EC regulation concerning the placing of plant protection products on the market (Regulation (EC) No. 1107/2009) contain no advice on conducting environmental risk assessments for biological control agents.

The regulation of introduction and release of IBCA is within the remit of national authorities and differs between European countries, some of which have yet to establish guidelines and procedures (Bigler et al. 2005; van Lenteren and Loomans 2006).

The international standards (EPPO, FAO, OECD) concerning the safe import and release of IBCAs, which are currently used as a basis for conducting the environmental risk assessment for $N$. typhlocybae, are in agreement on the key information necessary to assess the risk of IBCAs. Some differences exist with regard to the recommendations to carry out a pest risk analysis of the biological control agent prior to release and develop emergency action plans in case the BCA displays adverse properties, as well as concerning the detailed description of the required information.

For the environmental risk assessment for N. typhlocybae it was first necessary to determine the host range of the parasitoid to corroborate the existing information on its biology. In Europe, N. typhlocybae depends on the presence of its host species $M$. pruinosa, whereas three other flatid host species are known in North America (Guglielmino and Olmi 1997). Neodryinus typhlocybae has a narrow host range and will only attack the target species, as this is the sole host species for the parasitoid present in Austria (Strauss 2009). In Austria, several inoculative releases of $N$. typhlocybae would initially be necessary at sites heavily infested with $M$. pruinosa in Vienna and Graz. It is expected that N. typhlocybae would spread to surrounding infestation sites by natural means after a few years. As a consequence of the comparably cooler summer temperatures in Vienna and Graz, however, it is assumed that a smaller portion of the second generation of $N$. typhlocybae will emerge and that natural spread will be slow. At a new infestation site of $M$. pruinosa far away from the existing release sites, the beneficial insect would have to be released actively by humans because its natural rate of spread would probably be too low. The influence of the known hyperparasitoid $G$. areator on the population of N. typhlocybae should be considered, because the parasitisation performance of the latter species could be negatively influenced. In other biological control programmes, the introduction of two other dryinids, Gonatopus hospes Perkins and Haplogonatopus vitiensis Perkins, which were introduced against the sugarcane planthopper Perkinsiella saccharicida Kirkaldy, failed because of hyperparasitoids (Williams 1931). From the European countries where N. typhlocybae has been released there are no known reports of disrupted control of M. pruinosa due to hyperparasitoids.

\section{Conclusion}

Based on the degree of climate matching between its original location in North America and the potential release areas in Austria, establishment of N. typhlocybae in the target areas in Vienna and Graz is likely. It is assumed that $N$. typhlocybae will provide satisfactory longterm suppression of M. pruinosa, as it does in Slovenia, which has a similar climate to Austria. Biological control of $M$. pruinosa with N. typhlocybae in Austria is assumed to be advantageous compared to chemical treatments because sustainable management of the pest would be 
achieved and the use of large amounts of insecticides, which are often broad spectrum insecticides killing natural beneficial species, could be avoided (Nicoli et al. 1995; Debras et al. 1998). The environmental risk of the release of $N$. typhlocybae for the biological control of M. pruinosa in Austria is therefore considered very low.

\section{Acknowledgements}

The author thanks Univ. Doz. DI Dr. Sylvia Blümel (AGES, Institute for Sustainable Plant Production) for her valuable comments on the manuscript and Mag. (FH) Michael Schwarz (AGES, Institute for Data, Statistics and Risk Assessment) for assistance in creating the distribution maps. A special thanks to Angela Parker and Natascha Wickramasinghe for correcting the English writing. The author would like to thank the anonymous reviewers for their useful comments.

\section{REFERENCES}

Alma A, Ferracini C, Burgio G (2005) Development of a sequential plan to evaluate Neodryinus typhlocybae (Ashmead) (Hymenoptera: Dryinidae) population associated with Metcalfa pruinosa (Say) (Homoptera: Flatidae) infestation in northwestern Italy. Environ Entomol 34: 819-824.

Anagnou-Veroniki M, Papaioannou-Souliotis P, Karanastasi E, Giannopolitis CN (2008) New records of plant pests and weeds in Greece, 1990-2007. Hell Plant Prot J 1: 55-78.

Bundesamt für Ernährungssicherheit (2012) Authorized plant protection products. http://pmg.ages.at/pls/psmlfrz/pmgweb4\$ .Startup?z_user=www. Accessed 12 November 2012.

Bale J (2011) Harmonization of regulations for invertebrate biocontrol agents in Europe: progress, problems and solutions. J Appl Entomol 135: 503-513.

Barbattini R, Greatti M, Iob M, Sabatini AG, Marcazzan G, Colombo R (1991) Osservazioni su Metcalfa pruinosa (Say) e indagine sulle caratteristiche del miele derivato dalla sua melata. Apicoltura 7: 113-135.

Bélanger É, Lucas É (2011) Dominance of the multicoloured Asian lady beetle Harmonia axyridis in an undisturbed wild meadow ecosystem. Eur J Environ Sci 1: 1-14.

Bigler F, Bale JS, Cock MJW, Dreyer H, Greatrex R, Kuhlmann U, Loomans AJM, van Lenteren JC (2005) Guidelines on information requirements for import and release of invertebrate biological control agents in European countries. Biocontrol News Inf 26: $115-123$.

Cenderello K (2006) Studio del rapporto fra Metcalfa pruinosa (Say) e Neodryinus typhlocybae (Ashmead) mediante utilizzo di Geostatistica e GIS. PhD Thesis, Universita di Pisa.

Chapelle P, Morzieres JP, Malausa JC, Giuge L (2002) Metcalfa pruinosa, la cicadelle blanche, code de bonne conduite en pepiniere pour limiter sa propagation en midi-pyrenees. http://www .srpv-midi-pyrenees.com/_publique/draf_srpv/Lutte_biologique /Fiche_technique/FichePepMPi08_02Metcalfa.pdf.

Ciglar I, Barić B, Žužic I (1998) Biological control of Metcalfa pruinosa by the introduction of Neodryinus typhlocybae (Ashmead) (Hymenoptera: Dryinidae) to Croatia. Fragm Phytomedica et Herb 26: 95-99.
DAISIE (2008) Neodryinus typhlocybae. http://www.europe-aliens .org/speciesFactsheet.do? speciesId=51015. Accessed 9 May 2011.

Debras JF, Rieux R, Arcier FFD, Kretsczhmar A, Simon S (1998) Regulation of pear psyllid: importance and role of the orchard environment. Phytoma 510: 53-55.

ESRI, Inc., 380 New York St., Redlands, CA 92373. ArcMAP ${ }^{\mathrm{rw}}$ Version 10.0.

EPPO (2000) Safe use of biological control: import and release of exotic biological control agents. European and Mediterranean Plant Protection Organization Standard PM6/2(1). http://archives.eppo.org/EPPOStandards/PM6_BIOCONTL /pm6-02-e.doc.

FAO (2005) Guidelines for the export, shipment, import and release of biological control agents and other beneficial organisms. International Standard for Phytosanitary Measures No. 3. Food and Agriculture Organization of the United Nations, Rome, Italy. https://www.ippc.int/file _uploaded/1146657660135_ISPM3.pdf.

Fauna Europaea (2004) http://www.faunaeur.org. Accessed 19 April 2007.

Girolami V, Camporese P (1994) Prima moltiplicazione in Europa di Neodryinus typhlocybae (Ashmead) (Hymenoptera: Dryinidae) su Metcalfa pruinosa (Say) (Homoptera: Flatidae). Atti XVII Cong Naz It Entomologia, Udine, Italia, 13-18 June 1994.

Girolami V, Conte L, Camporese P, Benuzzi M, Rota Martir G, Dradi D (1996) Possibilità di controllo biologico della Metcalfa pruinosa. L'Informatore Agrario 52: 61-65.

Girolami V, Mazzon L (1999) Controllo di Metcalfa pruinosa ad opera di Neodryinus typhlocybae. L'Informatore Agrario 55: $87-91$.

Girolami V, Mazzon L (2001) Esperienze di lotta biologica e integrata a Metcalfa pruinosa con Neodryinus typhlocybae. Atti Acc Naz It Entomol 49: 165-184.

Greatti M, Zandigiacomo P, Rossi L (1994) Predatori di Metcalfa pruinosa (Say) in Friuli. Atti XVII Cong Naz It Entomologia, Udine, Italy, 13-18 June 1994.

Greatti M, Barbattini R (2003) Metcalfa infestation and honey production. A method of estimation. Notiziario ERSA 16: 50-52. http://www.ersa.fvg.it/informativa/notiziario-ersa /anno/2003/6/1033.pdf/fss_download/file. Accessed 17 November 2012 .

Guglielmino A, Olmi M (1997) A host-parasite catalog of the world Dryinidae (Hymenoptera: Chrysidoidea). Contrib Entomol Int 2: $165-298$.

Hoddle MS (2004) Analysis of fauna in the receiving area for the purpose of identifying native species that exotic natural enemies may potentially attack. In: van Driesche RG, Reardon $R$ (eds) Assessing host ranges for parasitoids and predators used for classical biological control: a guide to best practice. United States Department of Agriculture Forest Health Technology Enterprise Team, Morgantown, West Virginia.

Höller C, Borgemeister C, Haardt H, Powell W (1993) The relationship between primary parasitoids and hyperparasitoids of cereal aphids: an analysis of field data. J Anim Ecol 62: 12-21.

Jermini M, Brunetti R, Bonavia M (2000) Introduzione di Neodryinus typhlocybae per il contenimento biologico di Metcalfa pruinosa: prime esperienze in Svizzera. Atti del Convegno "Metcalfa pruinosa: diffusione nel continente europeo e prospettive di controllo biologico", S. Donato Milanese, 21. Oct 1999. Sherwood 55 (Suppl.): 18-20.

Kahrer A, Strauss G, Stolz M, Moosbeckhofer R (2009) Beobachtungen zur Faunistik und Biologie der vor kurzem nach Österreich eingeschleppten Bläulingszikade (Metcalfa prui- 
nosa). Observations on the biology and distribution of the recently introduced planthopper Metcalfa pruinosa. Beiträge zur Entomofaunistik 10: 17-30.

Lucchi A, Wilson SW (2003) Notes on Dryinid Parasitoids of Planthoppers (Hymenoptera: Dryinidae; Hemiptera: Flatidae, Issidae). J Kans Entomol Soc 76: 73-75.

Maisonhaute JÉ, Lucas É (2011) Influence of landscape structure on the functional groups of an aphidophagous guild: Active-searching predators, furtive predators and parasitoids. Eur J Environ Sci 1: 41-50.

Malausa JC (2000) Esperienze di introduzione di Neodryinus typhlocybae: in Francia. Atti del Convegno "Metcalfa pruino$s a$ : diffusione nel continente europeo e prospettive di controllo biologico", S. Donato Milanese, 21. Oct 1999, Sherwood 55 (Suppl.): 15-17.

Malausa JC, Giuge L, Fauvergue X (2003) Acclimatation et dispersion en France de Neodryinus typhlocybae (Ashmead) (Hymenoptera, Dryinidae) introduit pour lutter contre Metcalfa pruinosa (Say) (Hemiptera, Flatidae). Bull Soc Entomol Fr 108 97-102.

Malumphy C, Baker R, Cheek S (1994) Citrus planthopper, Metcalfa pruinosa. Central Science Laboratory (UK), Plant pest notice No. 19.

McDougall SJ, Mills NJ (1997) Dispersal of Trichogramma platneri Nagarkatti (Hym., Trichogrammatidae) from point-source releases in an apple orchard in California. J Appl Entomol 121: 205-209.

Messing R, Roitberg B, Brodeur J (2006) Measuring and predicting indirect impacts of biological control: competition, displacement and secondary interactions. In: Bigler F, Babendreier D, Kuhlmann U (eds) Environmental impact of invertebrates for biological control of arthropods: methods and risk assessment. CAB Int. Wallingford, pp 114-131.

Nearctica (1998) http://www.nearctica.com.

Nicoli G (1997) Biological control of exotic pests in Italy: recent experiences and perspectives. OEPP/EPPO Bull 27: 69-75.

OECD (2004) Guidance for information requirements for regulation of invertebrates as biological control agents (IBCAs). Organisation for Economic Co-operation and Development Series on Pesticides No 21. http://www.oecd.org/dataoecd /6/20/28725175.pdf.

Olmi M (2000) Bio-ecologia degli Imenotteri Driinidi e loro impiego in programmi di lotta biologica. In: Lucchi A (ed) La Metcalfa negli ecosistemi italiani. Arsia, Florenz, Italy, pp 93-117.

Pflanzenschutzmittelgesetz (2011) Bundesgesetz, mit dem ein Pflanzenschutzmittelgesetz 2011 und ein Pflanzenschutzgesetz 2011 erlassen werden (Agrarrechtsänderungsgesetz 2010). http://www.ris.bka.gv.at/Dokumente/BgblAuth /BGBLA_2011_I_10/BGBLA_2011_I_10.html. Accessed 24 May 2011.

Regulation (EC) No 1107/2009 of the European Parliament and of the Council of 21 October 2009 concerning the placing of plant protection products on the market and repealing Council Directives 79/117/EEC and 91/414/EEC. http://eur-lex.europa.eu/LexUriServ/LexUriServ.do?uri=OJ :L:2009:309:0001:01:EN:HTML.

Stewart AJA, New TR (2007) Insect conservation in temperate biomass: issues, progress and prospects. In: Stewart AJA, New TR, Lewis OT (eds) Insect Conservation Biology: proceedings of the Royal Entomological Society's 23rd Symposium. CABI Publishing, Wallingford, pp 1-33.
Strauss G (2009) Host range testing of the nearctic beneficial parasitoid Neodryinus typhlocybae. BioControl 54: 163-171.

Strauss G (2010) Pest risk analysis of Metcalfa pruinosa in Austria. J Pest Sci 83: 381-390.

Suchail S, Guez D, Belzunces LP (2000) Acute and chronic toxicity of imidacloprid and its metabolites in Apis mellifera. In: Pélissier C, Belzunces LP (eds) Hazards of pesticides to bees. IOBC/ WPRS Bull 23: 7 .

Tommasini MG, Mosti M, Dradi D, Girolami V (1998) Lotta biologica contro Metcalfa pruinosa con Neodryinus typhlocybae: prime esperienze sullacclimatazione del parassitoide in Emilia-Romagna. Inf Fitopat 48: 51-54.

Van Lenteren JC, Loomans AJM (2006) Environmental risk assessment: methods for comprehensive evaluation and quick scan. In: Bigler F, Babendreier D, Kuhlmann U (eds) Environmental impact of invertebrates for biological control of arthropods. Methods and risk assessment. CABI Publishing, Wallingford, UK.

Van Lenteren JC, Loomans AJM, Babendreier D, Bigler F (2008) Harmonia axyridis: an environmental risk assessment for Northwest Europe. BioControl 53: 37-54.

Villani A, Zandigiacomo P (1999) Immissione in Friuli-Venezia Giulia dell'entomofago Neodryinus typhlocybae, antagonista di: Metcalfa pruinosa. Inf Fitopat 49: 47-51.

Viggiani G, Alma A, Foschi S, Lucchi A, Mazzon L (2004) Parassitoidi di Neodryinus typhlocybae (Ashmead) (Hymenoptera: Dryinidae) in Italia. Boll Lab Ent Agr Filippo Silvestri 58: 101-105.

Visentini A (1998) Valutazione della parassitizzazione in natura e determinazione del sesso in Neodryinus typhlocybae (Ashmead). PhD Thesis, University of Padova.

Wajnberg E, Bernstein C, van Alphen J (2007) Behavioral ecology of insect parasitoids - from theoretical approaches to field applications. Blackwell, Oxford.

Williams FX (1931) Handbook of the insects and other invertebrates of Hawaiian sugar cane fields. 400pp., Honolulu, Hawaii. In: Olmi M (ed) The Dryinidae and Embolemidae (Hymenoptera: Chrysidoidea) of Fennoscandia and Denmark. Fauna Entomol Scand, EJ Brill, Leiden, New York, Köln.

Wilson SW, McPherson JE (1981) Life Histories of Anormenis septentrionalis, Metcalfa pruinosa, and Ormenoides venusta with Descriptions of Immature Stages. Ann Entomol Soc Am 74: 299-311.

Wright MG, Hoffmann MP, Chenus SA, Gardner J (2001) Dispersal Behavior of Trichogramma ostriniae (Hymenoptera: Trichogrammatidae) in Sweet Corn Fields: Implications for Augmentative Releases against Ostrinia nubilalis (Lepidoptera: Crambidae). Biol Control 22: 29-37.

World Climate (1996) http://www.worldclimate.com.

Zangheri S, Donadini P (1980) Comparsa nel Veneto di un omottero neartico: Metcalfa pruinosa Say (Homoptera, Flatidae). Redia 63: 301-306.

Zandigiacomo P, Villani A (2003) Contro la Metcalfa. Bioagricultura 80: 48-52.

Zentralanstalt für Meteorologie und Geodynamik (2002) Klimadaten von Österreich 1971-2000, Wien. http://www.zamg.ac.at.

Žežlina I, Milevoj L, Girolami V (2001) Wasp Neodryinus typhlocybae Ashmead - successful predator and parasitoid for reducing the population of flatid planthopper (Metcalfa pruino$s a$ Say) also in Slovenia. Zbornik Biotehniske fakultete Univerze v Ljubljani (Slovenia) 77: 215-225. 